\title{
Reconciling strontium-isotope and $\mathrm{K}-\mathrm{Ar}$ ages with biostratigraphy: the case of the Urgonian platform, Early Cretaceous of the Jura Mountains, Western Switzerland
}

\author{
Alexis Godet $\cdot$ Karl B. Föllmi $\cdot$ Peter Stille $\cdot$ Stéphane Bodin $\cdot$ \\ Virginie Matera $\cdot$ Thierry Adatte
}

Received: 6 July 2010/Accepted: 7 January 2011/Published online: 17 March 2011

(C) Swiss Geological Society 2011

\begin{abstract}
During the late Early Cretaceous, the shallowwater domains of the western Tethys are characterized by the widespread deposition of Urgonian-type carbonates rich in rudists, corals and other oligotrophic, shallow-marine organisms. In the Helvetic Alps, the Urgonian occurrences have been dated by ammonite biostratigraphy as Late Barremian and Early Aptian. For the more proximal occurrences in the western Swiss Jura, a recent age model based on bio-, chemo- and sequence stratigraphy has been proposed, which allows for an improved correlation with the Helvetic counterparts. In order to corroborate the recently proposed age model for the Jura, a set of well-preserved rhynchonellids collected from five different lithostratigraphical formations
\end{abstract}

Editorial handling: A.G. Milnes.

A. Godet · K. B. Föllmi - T. Adatte

Institut de Géologie et Paléontologie, Quartier UNIL-Dorigny,

Bâtiment Anthropole, 1015 Lausanne, Switzerland

A. Godet $(\bowtie)$ K. B. Föllmi · S. Bodin · V. Matera · T. Adatte Institut de Géologie et Hydrogéologie, Université de Neuchâtel, rue Emile Argand 11, CP158, 2009 Neuchâtel, Switzerland

e-mail: Alexis.Godet@unil.ch

P. Stille

Laboratoire d'Hydrologie et de Géochimie de Strasbourg, UMR 7517, EOST, Université de Strasbourg, INSU/CNRS, 67084 Strasbourg, France

S. Bodin

Institute for Geology, Mineralogy and Geophysics,

Ruhr-Universität, Bochum, Universitätsstrasse 150,

44801 Bochum, Germany

\section{Matera}

Laboratoire LAICA-Département Métrologie des Polluants, INRS, Rue du Morvan CS 60027, 54519 Vandoeuvre-lès-Nancy Cedex, France and members ("Marnes bleues d'Hauterive", "Marnes d'Uttins", basal marly layers within the "Urgonien Jaune", "Marnes de la Russille", "Urgonien Blanc") has been analysed for its strontium-isotope ratios $\left({ }^{87} \mathrm{Sr} /{ }^{86} \mathrm{Sr}\right)$. In addition, $\mathrm{K}-\mathrm{Ar}$ dating was performed on well-preserved glauconite grains from two different levels ("Marnes d'Uttins" and a basal layer within the "Urgonien Jaune"). The correlation of the $\mathrm{Sr}$-isotope data set with a belemnitebased, ammonite-calibrated reference curve provides an age model which is coherent with recently published ages based on calcareous nannofossil biostratigraphy and the correlation of trends in chemo- and sequence stratigraphy. $\mathrm{K}-\mathrm{Ar}$ dating on well-preserved glauconite grains from the "Marnes d'Uttins" and lowermost part of the "Urgonien Jaune" delivered ages of $127.5 \pm 2.3$ and $130.7 \pm 2.6 \mathrm{Ma}$, respectively. Whereas the age of the glauconitic level near the base of the "Urgonien Jaune" is chronostratigraphically meaningful, the K-Ar age of the "Marnes d'Uttins" appears too young relative to the presently used time scale. This may be related to rejuvenation of the $\mathrm{K}-\mathrm{Ar}$ chronometer due to post-depositional Ar loss, most likely during hardground formation. The ages obtained here confirm the Late Barremian age for the onset of the Urgonian platform, an age which is conform with ages obtained in the Helvetic Alps and elsewhere along the northern Tethyan margin.

Keywords Strontium isotopes - Glauconite · Potassium-argon dating · Rhynchonellids · Hauterivian · Barremian

\section{Introduction}

The dating of shallow-marine carbonates represents a challenging stratigraphic topic, especially since associated 
fossils may be sometimes facies dependent and of correspondingly low biostratigraphic value. To this comes that these rocks may be strongly affected by diagenesis, which impedes the use of direct dating or correlation with adjacent, well-dated basinal sections by means of geochemical proxies, such as the $\delta^{13} \mathrm{C}$ record. This is specifically the case for Early Cretaceous shallow-water carbonates and marls of the western Swiss Jura Mountains, for which the establishment of an age model has been riddled with difficulties and resulting controversies (Clavel et al. 2007; Godet et al. 2010).

The Early Cretaceous succession of the Jura Mountains was part of a vast carbonate platform and ramp system, which evolved along the northern Tethyan margin, and culminated in the installation of the so-called Urgonian platform. The remains of the northern Tethyan carbonate platform are preserved in Spain, southern and eastern France, Switzerland, Austria, southeastern Germany and eastward in the Carpathians (e.g., Funk et al. 1993; Michalik, 1994; Arnaud et al. 1998; Bernaus et al. 2003). In these localities, the Urgonian deposits resulted from largely photozoan carbonate ecosystems, which were dominated by rudists, large benthic foraminifera (orbitolinids) and other benthic organisms (e.g., dasycladacean algae, corals, stromatoporoids). Commonly, a Late Barremian age is assumed for the installation of the Urgonian platform; however, older ages have been proposed for the Provence region in southern France (e.g., Masse 1993) and for the Jura Mountains (e.g., Clavel et al. 2007).

A similar platform evolution is reported from the southern Tethyan margin. The Berrani Formation from Tunisia, and the Kharaib and Qishn Formations from Oman, are characterized by rudist-rich facies, and are dated as Barremian (e.g., Ben Youssef and Peybernès 1986; Pittet et al. 2002; van Buchem et al. 2002, 2010; Immenhauser et al. 2004). In these areas, the appearance of Palorbitolina lenticularis would support a Late Barremian age (Arnaud 2005; Schroeder et al. 2010). The apparent synchronicity in the onset of Urgonian-type facies both on the northern and southern Tethyan margins suggests a generalized change in paleoecological conditions during the Late Barremian, which favoured an increase in oligotrophic conditions and promoted the rise of rudist-dominated, shallow-water communities (Föllmi et al. 2006; Schroeder et al. 2010).

In the western Swiss Jura, shallow-water sediments of middle to late Early Cretaceous age include the "Marnes bleues d'Hauterive" (Early Hauterivian in age), lower "Pierre Jaune de Neuchâtel" (Early Hauterivian), "Marnes d'Uttins" (late Early to possibly early Late Hauterivian), upper "Pierre Jaune de Neuchâtel" (Late Hauterivian), "Urgonien Jaune" (latest Hauterivian to middle Late Barremian), "Marnes de la Russille" (Late Barremian) and "Urgonien Blanc" (Late Barremian) (Fig. 1; Godet et al.
2010). The sedimentary succession of the lower "Pierre Jaune de Neuchâtel" to the "Urgonien Jaune" is characterized by heterozoan carbonate assemblages (dominated by bryozoans and crinoids), and punctuated by a series of major breaks in sediment accumulation, documented, for instance, by a glauconitic, phosphatic and silicified hardground at the base of the "Marnes d'Uttins", or by a glauconitic and phosphate-bearing horizon near the base of the "Urgonien Jaune" (Godet et al. 2010). The "Marnes de la Russille" mark the first appearance of corals and stromatoporoids, and the following "Urgonien Blanc" is characterized by the abundant occurrence of rudists and corals in typical Urgonian facies. These fossil groups are considered as part of a photozoan ecosystem (e.g., Renevier 1874; Blanc-Aletru 1995; Godet et al. 2010).

Hitherto, controversial age interpretations have hampered correlations between the western Swiss Jura successions, and especially its Urgonian members, and the better-dated successions of the Helvetic Alps and southeastern France (e.g., Arnaud-Vanneau and Arnaud 1990; Blanc-Aletru 1995; Godet 2006; Clavel et al. 2007; Godet et al. 2010). In the present study the potential of $\mathrm{Sr}$-isotope and $\mathrm{K}-\mathrm{Ar}$ dating tools is explored, in order to improve existing age models for the Lower Cretaceous sediments of the western Swiss Jura, and as such to refine their proper integration into a larger sequence-stratigraphical and palaeoceanographic framework. In spite of the complex diagenetic history of the Jura sediments, the Sr-isotope data set provides an age model which is coherent with recently published ages and which places the onset of the Urgonian platform in the Late Barremian. Also the $\mathrm{K}-\mathrm{Ar}$ age dates are partly consistent with earlier age determinations.

\section{Materials and methods}

In shallow marine carbonates, brachiopods may provide reliable information on the physico-chemical conditions of their depositional environments, as long as their diagenetic state is correctly assessed. This is especially true for rhynchonellids, which may be well suited for $\mathrm{Sr}$-isotope stratigraphy, as opposed to terebratulids, as the latter hold perforations in their shells (punctae), which may be filled by diagenetic calcite (e.g., Veizer et al. 1999; Voigt et al. 2003). In the present study 19 rhynchonellids from several sections in the cantons of Vaud and Neuchâtel (Fig. 2) have been sampled and analyzed for their ${ }^{87} \mathrm{Sr} /{ }^{86} \mathrm{Sr}$ ratios in order to derive $\mathrm{Sr}$ model ages. Both their geographical and stratigraphical locations, as well as their $\mathrm{Sr}$ isotope ratios, are reported in Table 1 and Fig. 1.

Two glauconitic levels have been sampled in the Eclépens section and dated by the $\mathrm{K}-\mathrm{Ar}$ method (samples 


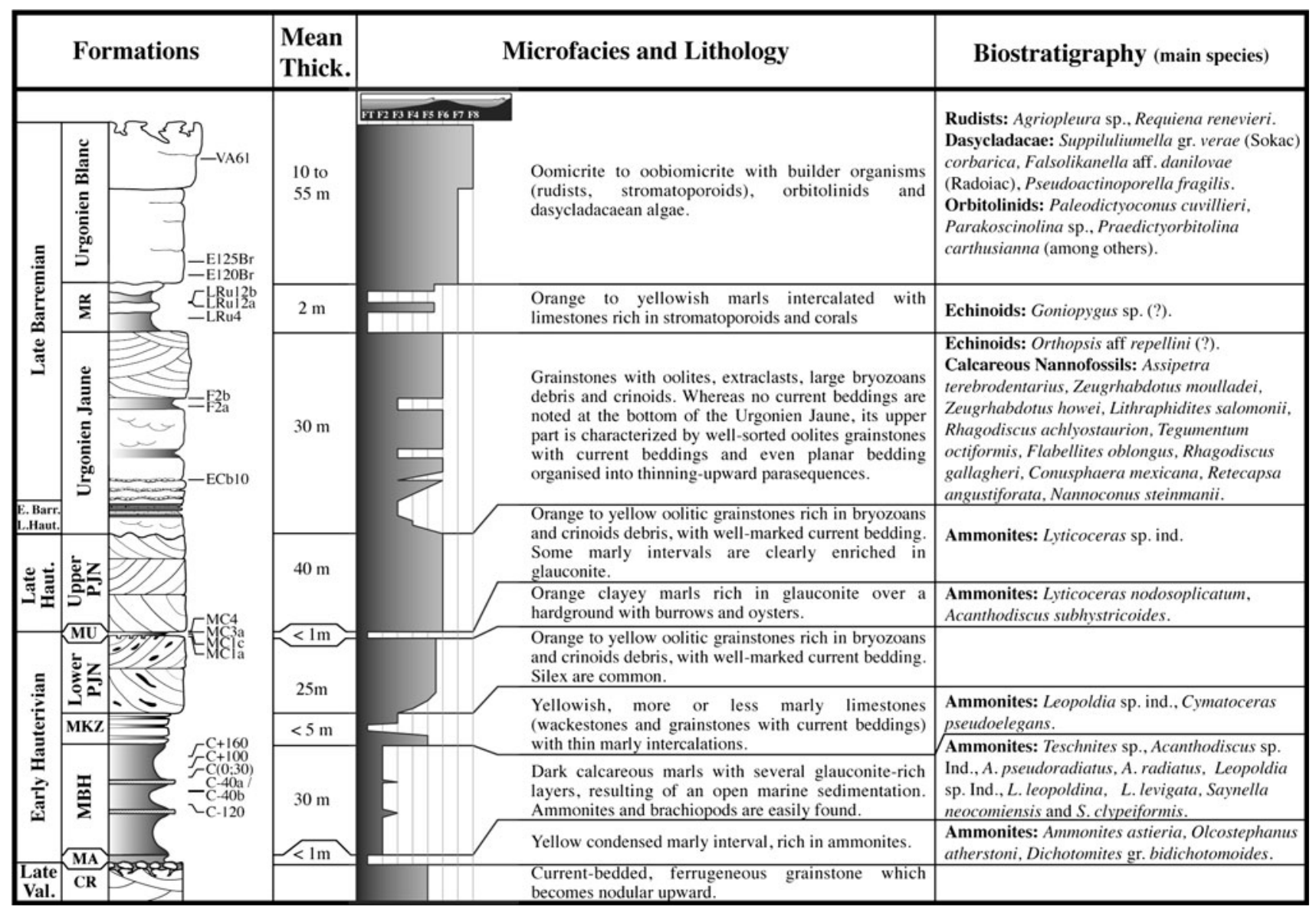

Fig. 1 Schematic representation of the Late Valanginian-Barremian sediments recovered in the western Swiss Jura (modified after Godet et al. 2010). Main lithological features, characteristic microfacies and fossils of biostratigraphic importance are reported on the right hand side (after Remane et al. 1989; Blanc-Aletru 1995; Godet 2006). The position of the analysed brachiopods is reported alongside the

$\mathrm{EC}_{\mathrm{II}} 21$ and $\mathrm{EC}_{\mathrm{II}} 57$ from the "Marnes d'Uttins" and the lowermost part of the "Urgonien Jaune", respectively, Fig. 3).

\subsection{Rhynchonellid sampling and preparation}

Only well-preserved rhynchonellid shells were sampled, i.e. broken or incomplete fossils were discarded. They were cleaned using metallic brushes and needles, until the main part of the adhered sediments was removed, and they were then washed in an ultrasonic bath in order to remove fine particles adhered to their surface. The brachiopods were subsequently sawn along the median longitudinal plane of symmetry and one half of each shell was used to prepare thin sections for scanning electron microscopy (SEM) and cathodoluminescence investigations. The second half was polished using a dental microdrill in order to remove the primary layer, which may have been subjected to stronger diagenetic overprint relative to the secondary layer lithological column. Abbreviations of the lithostratigraphical formation and member names are: $C R$ Calcaire Roux, $M A$ Marnes à Astieria, $M B H$ Marnes bleues d'Hauterive, $M K Z$ Mergelkalk Zone, $P J N$ Pierre Jaune de Neuchâtel, $M U$ Marnes d'Uttins, MR Marnes de la Russille

(Carpenter and Lohmann 1995). Subsequently, samples were rinsed with ultrapure water. Powder was obtained from the dried shells using a microdrilling Dremel device equipped with a carburised titanium drill, which was washed with $10 \% \mathrm{HCl}$ and ultrapure water between each sample treatment in order to avoid any contamination, following the procedure of Voigt et al. (2003). Each powdered sample was split into two aliquots for ${ }^{87} \mathrm{Sr} /{ }^{86} \mathrm{Sr}$ and elemental analyses, respectively.

\subsection{Analyses performed to constrain the diagenetic state of the shells}

The preservation of the rhynchonellid shells was checked for diagenetic alteration by the following three approaches. Thin sections of the shell material were first examined using an optical microscope, and then the microstructure of a selection of shells was observed using a SEM (Phillips SX 50M) at the Institute of Microtechnics of the University 


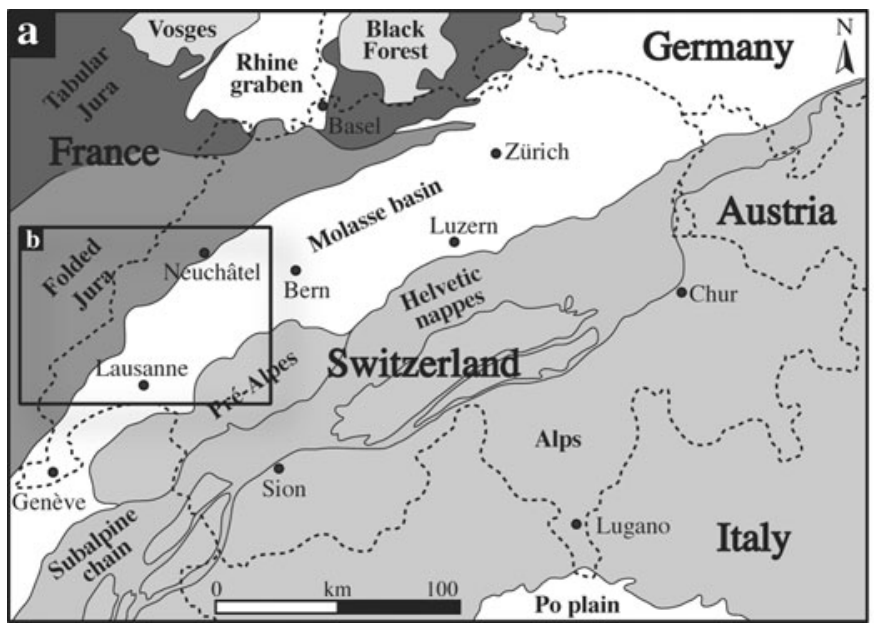

Fig. 2 a General structural overview of Switzerland showing the Jura domain in dark grey (modified from Bodin et al. 2006a); b studied outcrops are located on the close-up [ 1 Cressier, 2 Neuchâtel sections

of Neuchâtel. Secondly, evidence for recrystallisation or mineralogical changes was searched for on the same set of thin sections, by means of cathodoluminescence microscopy (CL8200 MK4, CITL), at the Institute of Geology and Palaeontology of the University of Fribourg. Finally, the concentrations of $\mathrm{Sr}, \mathrm{Ca}, \mathrm{Mg}$ and $\mathrm{Mn}$ were measured using a quadrupole ICP-MS device (Perkin-Elmer ELAN 6100), at the Geological Institute of the University of Neuchâtel, in order to compare the results with values obtained for well-preserved brachiopods (e.g., Fig. 3 in Korte et al. 2003; Fig. 4 in Shields et al. 2003, and references therein). About $5 \mathrm{mg}$ of brachiopod powder was dissolved in $10 \mathrm{~mL}$ of $0.6 \mathrm{M} \mathrm{HNO}_{3}$ (suprapur, Merck), using the procedure of Boyle and Keigwin (1985/86).

\subsection{Strontium isotope measurement}

Strontium-isotope analyses were performed at the Laboratoire d'Hydrologie et de Géochimie de Strasbourg (LHyGeS, CNRS). The procedure is similar to the one described by Stille et al. (1994). Powdered samples were treated with $0.5 \mathrm{M}$ acetic acid in order to remove $\mathrm{Sr}$-rich calcite overgrowths and rinsed with distilled water prior to dissolution in $6 \mathrm{~N} \mathrm{HCl}$. Chemical separations were performed using ammonium citrate and 4.0 and $6.0 \mathrm{M} \mathrm{HCl}$ as eluent through AG 50W-X12 (200-400) ion exchange resin in $1 \mathrm{ml}$ quartz columns for $\mathrm{Sr}$ and bulk rare-earth element separation. The blank at the time of analysis was $<1 \mathrm{ng}$ for Sr. Strontium was measured using triple Re filament assemblies and single oxidised Ta filaments. The Sr isotope measurements were performed on a fully automatic VG Sector mass spectrometer with a six cups multicollector. The ratio ${ }^{87} \mathrm{Sr} /{ }^{86} \mathrm{Sr}=0.1194$ was used for fractionation correction. During the measuring period, the NBS $987 \mathrm{Sr}$

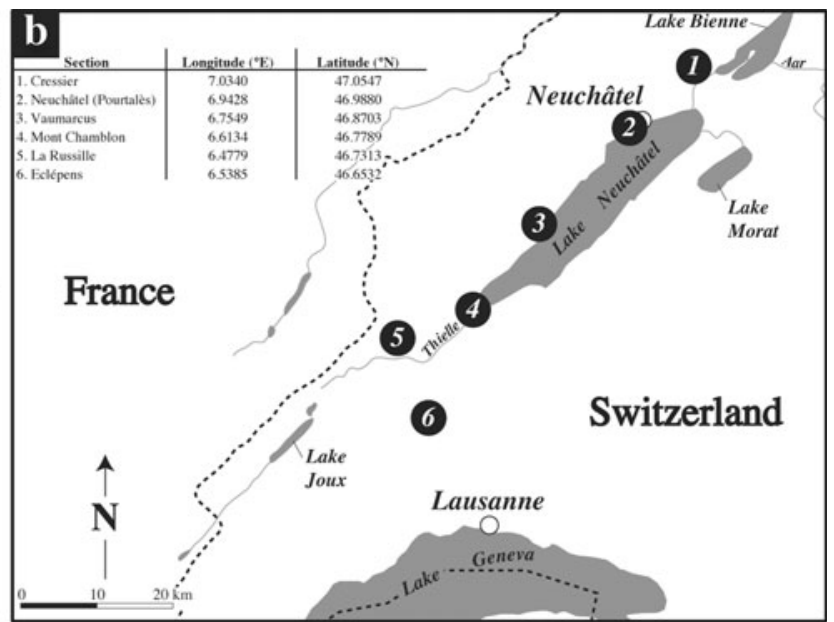

(Pourtalès hospital), 3 Vaumarcus, 4 Mont Chamblon, 5 La Russille, 6 Eclépens quarry]

standard yielded ${ }^{87} \mathrm{Sr} /{ }^{86} \mathrm{Sr}=0.710258 \pm 5( \pm \mathrm{SD}, n=9)$; 80-100 ratios for $\mathrm{Sr}$ were collected to achieve adequate precision.

\subsection{Glauconite separation and X-ray diffractometry}

Bulk samples were first dried at $40^{\circ} \mathrm{C}$ overnight, then roughly crushed using a "jaw" crusher. They were subsequently sorted into four size classes using a wet granulometric column ( $>1 \mathrm{~mm}, 1 \mathrm{~mm}-250 \mu \mathrm{m}, 250-125 \mu \mathrm{m}$ and $125-63 \mu \mathrm{m}$ ). Each sieve was washed until the residue was cleaned of all clay particles, then transferred into Petri boxes using deionised water and heated at $40^{\circ} \mathrm{C}$ in an oven until all water was evaporated.

Each granulometric fraction was then examined under a binocular; as the main part of the glauconitic particles was concentrated in the $>1 \mathrm{~mm}$ and the $1 \mathrm{~mm}-250 \mu \mathrm{m}$ fractions, the other granulometric classes were set apart. All dark green, poorly-rounded grains were supposed to be of (sub-) autochthonous origin, following the recommendations of previous studies (e.g., Odin and Matter 1981; Odin and Fullagar 1988); they were separated by hand picking and washed several times using deionised water. Most of the particles (i.e., quartz, calcite) attached on the surface of glauconitic grains were removed using ultrasonic baths, during at least $10 \mathrm{~min}$ for each sample. Finally, each sample was split into two aliquots for XRD analysis and $\mathrm{K}-\mathrm{Ar}$ dating, respectively.

In view of the XRD analyses, the separated glauconitic grains $(1 \mathrm{~mm}-250 \mu \mathrm{m}$ fraction) were hand crushed using an agate mortar, in order to produce a homogenous powder. The latter was solubilised in deionised water, deposited on clean glass plates and analysed with a XDS Scintag 2000 Diffractometer using an angular range of $2^{\circ}-65^{\circ} 2 \theta$, a step 


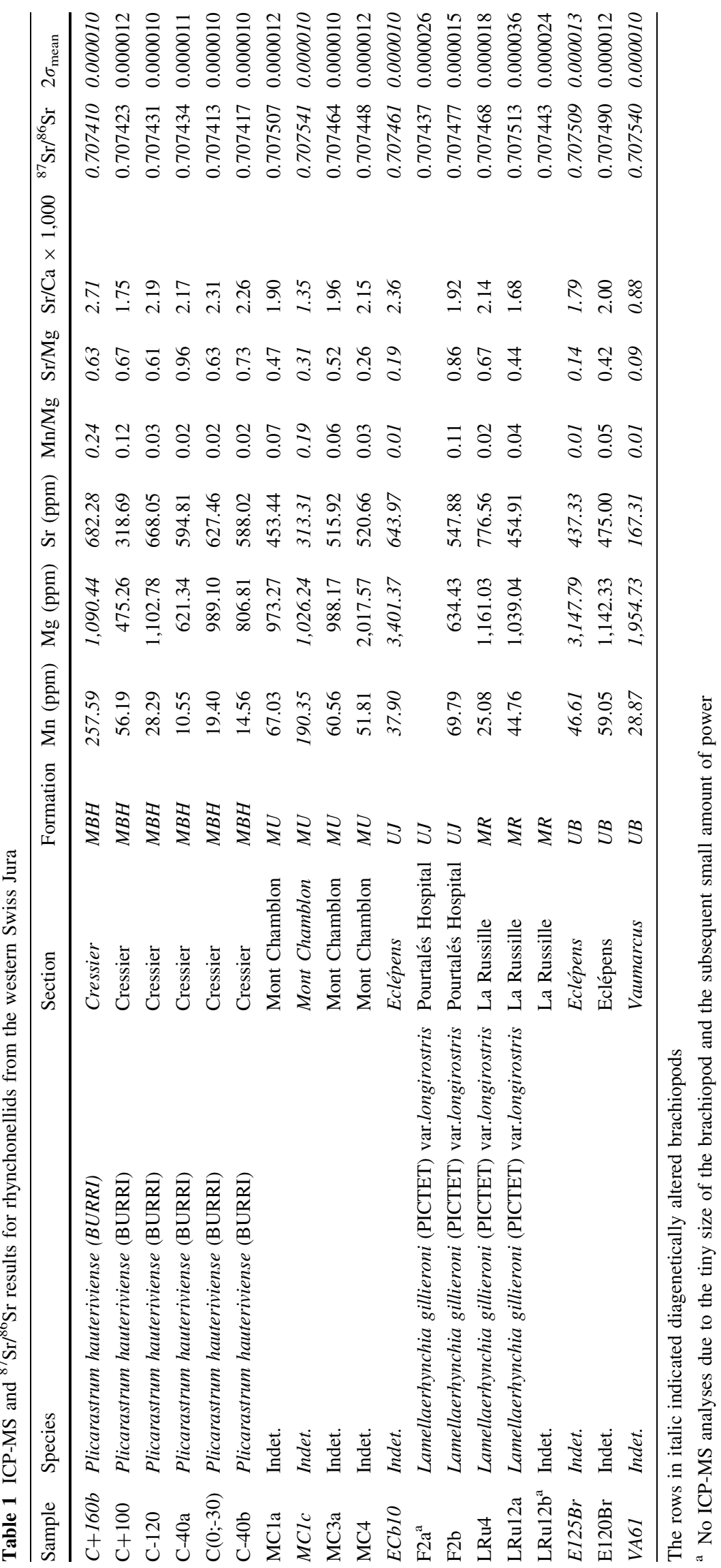




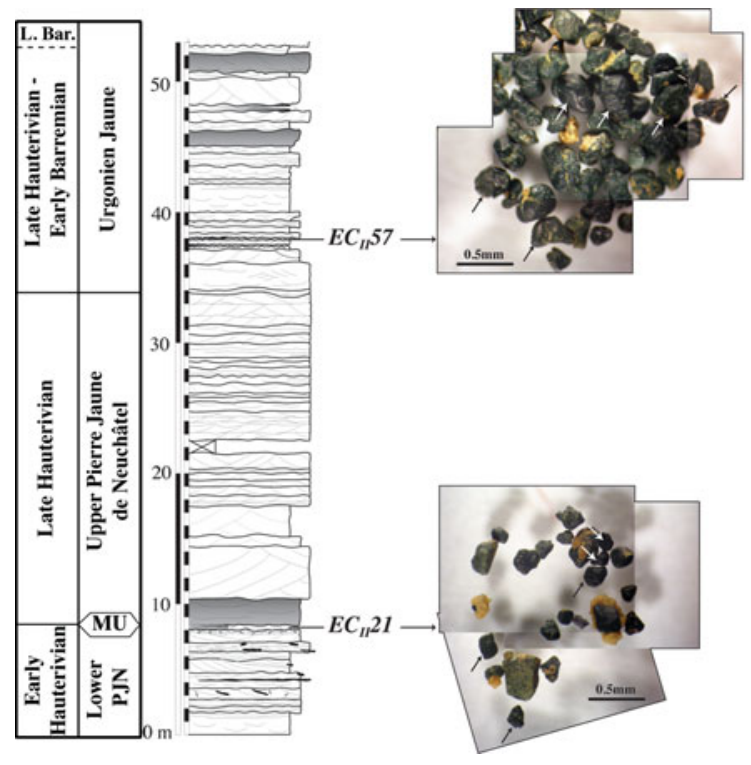

Fig. 3 Position of the two analysed glauconite samples within the lower part of the Eclépens section (see Godet et al. 2010 for a detailed sedimentological description). On the right hand side, photographs of

size of $0.03^{\circ} 2 \theta$ and a scan rate of $0.2^{\circ} 2 \theta \mathrm{min}^{-1}$. The obtained diffractograms were subsequently compared with the values of diffraction peaks of the glauconite $(1 \mathrm{M})$ standard JCPDS 09-0439 (dark dotted lines on Fig. 3), using the software MacDiff $v$ 4.2.5; the majority of the peaks of samples $\mathrm{EC}_{\mathrm{II}} 21$ and $\mathrm{EC}_{\mathrm{II}} 57$ are correlatable with the standard's data. Moreover, the position of the 060 peak at $61.2^{\circ} 2 \theta\left(61.35^{\circ} 2 \theta\right.$ in Tab 7.4 in Moore and Reynolds 1997), suggests that the separated grains correspond to relatively evolved glauconite.

\subsection{Potassium and argon measurement}

Samples were analysed at the Laboratoire d'Hydrologie et de Géochimie (LHyGeS) in Strasbourg (France). The procedure used is similar to the one described by Schaltegger et al. (1995). For determination of the K concentration, ca. $50-60 \mathrm{mg}$ of dry sample were heated at $850^{\circ} \mathrm{C}$ for $24 \mathrm{~h}$ prior to digestion, to oxidize the organic matter. Dissolution was achieved in screwed Savillex vials containing HF and $\mathrm{HNO}_{3}$ during 5 days. The dissolved samples were diluted with $2 \% \mathrm{HNO}_{3}$ and their concentration was measured by atomic absorption spectrometry with an analytical accuracy of ca. $\pm 1 \%$. The Ar-isotope composition was measured on approximately $50 \mathrm{mg}$ of sample material, which was previously dried overnight at $110^{\circ} \mathrm{C}$, using an Ar-extraction method close to that described by Bonhomme et al. (1975) and an upgraded AEI MS-20 mass spectrometer. The isotope ratios are corrected for blank and mass discrimination. Analysis of samples replicates implied a precision of $\pm 2.3 \mathrm{Ma}\left(\mathrm{EC}_{\mathrm{II}} 21\right)$ and $\pm 2.6 \mathrm{Ma}\left(\mathrm{EC}_{\mathrm{II}} 57\right)$. the glauconitic grains and the corresponding diffractograms are shown; only dark-green and clean glauconitic grains were hand picked (white and black arrows)

\section{Results}

\subsection{Microscopy and elemental geochemistry}

SEM analyses on a selection of thin sections of representative rhynchonellid brachiopods $(n=6)$ showed no trace of dissolution or recrystallisation, and in all cases the fibrous microstructure of the secondary layer was well discernable (Fig. 4; compare with Veizer et al. 1999; Fig. 2 in Korte et al. 2003; Fig. 3 in Shields et al. 2003). The inspection of the complete set of samples $(n=19)$ by cathodoluminescence microscopy revealed the systematic absence of luminescence in the secondary shell layer, thus confirming the absence of post-depositional mineralogical change, whereas the shell infill displayed an orange luminescent colour (Fig. 4).

$\mathrm{Sr}, \mathrm{Ca}, \mathrm{Mg}$ and $\mathrm{Mn}$ contents were determined in the sampled rhynchonellids (Table 1). Sr and $\mathrm{Mg}$ concentrations respectively range between 167.31 and $776.56 \mathrm{ppm}$, 475.26 and 3,401.37 ppm, whereas the Mn contents of the fossils are varying from 10.55 to $257.59 \mathrm{ppm}$. In order to compare these results with published dataset, $\mathrm{Mn} / \mathrm{Mg}, \mathrm{Sr} /$ $\mathrm{Mg}$ and $\mathrm{Sr} / \mathrm{Ca} \times 1,000$ ratios were calculated; the results are also reported in Table 1.

\subsection{Strontium isotope ratios}

A total of 19 rhynchonellids from the western Swiss Jura were analysed for their Sr-isotope compositions (Fig. 6; Table 1). The measured ${ }^{87} \mathrm{Sr} /{ }^{86} \mathrm{Sr}$ ratios are significantly variable between the different studied formations, with average values 
Fig. 4 Microscopic

investigations performed on the rhynchonellid brachiopod LRu4 (La Russille section; see BlancAletru 1995, for description and location). a Pictures of the brachiopod LRu4; dash lines represent the orientation of the sections analysed; b, c SEM microphotographs of rhynchonellid LRu4 show good preservation of the fibrous structure of the secondary layer; d, e On cathodoluminescence microphotographs (e), the secondary layer of sample LRu4 is non-luminescent, whereas it is translucent in natural light $(\mathbf{d})$, suggesting the absence of recrystallisation of the low-Mg calcite layer
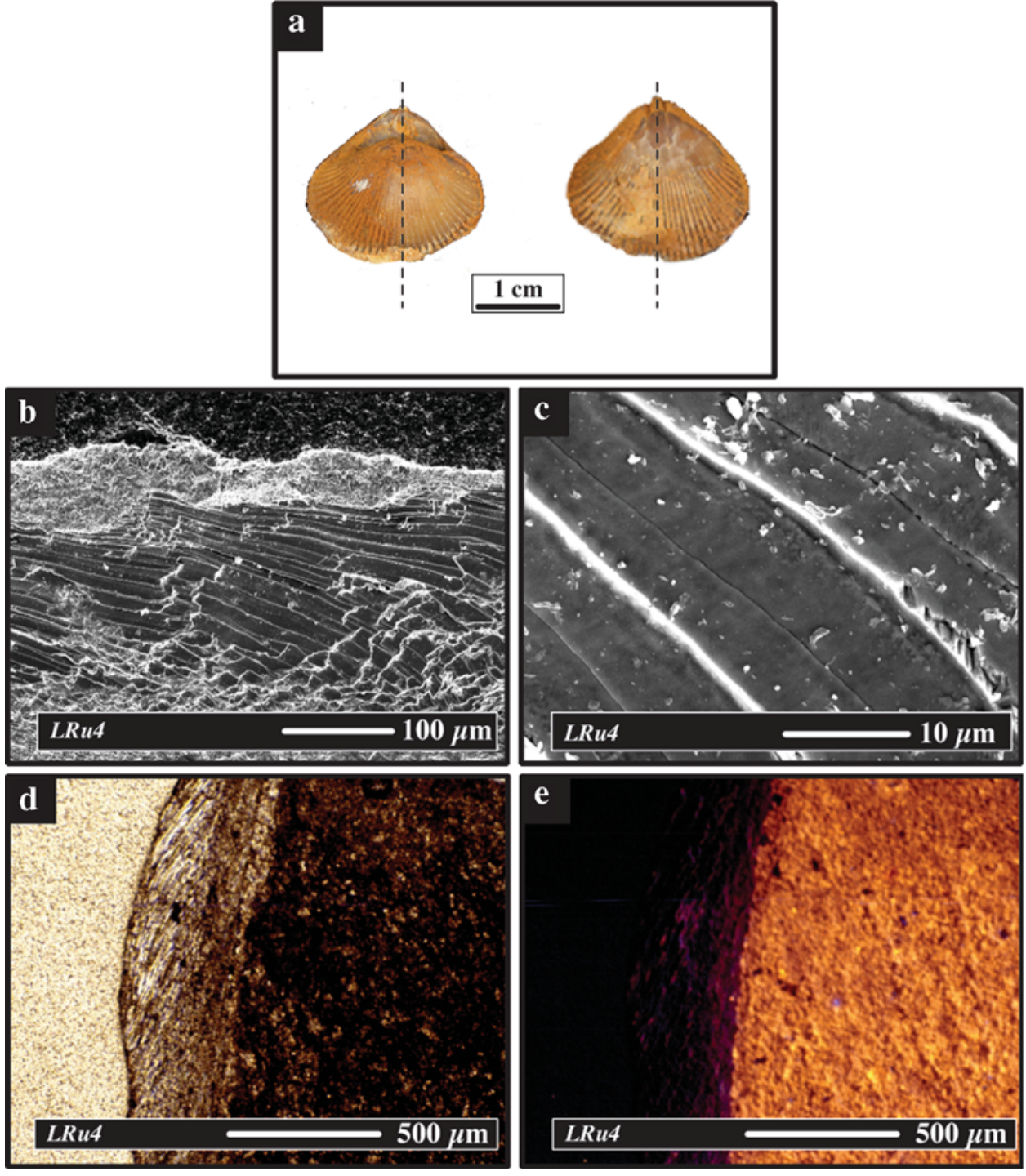

of $0.707423,0.707473,0.707457,0.707474$ and 0.707490 for rhynchonellids from the "Marnes bleues d'Hauterive", "Marnes d'Uttins", "Urgonien Jaune", "Marnes de la Russille" and "Urgonien Blanc", respectively. Moreover, the range of values within one formation varies from 0.000021 ("Marnes bleues d'Hauterive") up to 0.00007 ("Marnes de la Russille"), whereas the confidence on measurement rises up to 0.000036 ( $2 \sigma_{\text {mean }}$; sample LRu12a in Table 1) for one sample from the "Marnes de la Russille".

Although long-term ${ }^{87} \mathrm{Sr} /{ }^{86} \mathrm{Sr}$ trends have not been drawn due to the scarcity of data, it is important to emphasize that values from the "Marnes bleues d'Hauterive" are generally lower than values from the "Marnes d'Uttins". The latter are slightly less radiogenic than measurements performed on material from the "Urgonien Jaune" and the "Marnes de la Russille" (Fig. 6). Finally, a maximum in the ${ }^{87} \mathrm{Sr} /{ }^{86} \mathrm{Sr}$ dataset is observed in the "Urgonien Blanc" (0.707540 for sample VA61, Table 1); as this uppermost value is even higher than any measurements performed in belemnites, its validity may have to be called into question.

\section{3 $\mathrm{K}$-Ar dating of glauconite}

Glauconite delivered ages that are coherent with $\mathrm{Sr}$ model ages, as sample $\mathrm{EC}_{\mathrm{II}} 21$ ("Marnes d'Uttins") and $\mathrm{EC}_{\mathrm{II}} 57$ (lowermost part of the "Urgonien Jaune") yield age of

Table 2 Results of the K-Ar dating on glauconite grains from the Marnes d'Uttins and from a glauconite layer near the base of the Urgonien Jaune in the Eclépens quarry

\begin{tabular}{lllll}
\hline Samples & $\mathrm{K}_{2} \mathrm{O}(\%)$ & Ar* $\left.^{*} \%\right)$ & Age (Ma) & Error (Ma) \\
\hline $\mathrm{EC}_{\mathrm{n}} 21$ & 6.47 & 97.36 & 127.5 & \pm 2.3 \\
$\mathrm{EC}_{\mathrm{n}} 57$ & 6.03 & 95.18 & 130.7 & \pm 2.6 \\
\hline
\end{tabular}

Ar* refers to radiogenic Argon 
$127.5 \pm 2.3$ and $130.7 \pm 2.6 \mathrm{Ma}$, respectively (Table 2). Both ages are identical within analytical uncertainty.

\section{Discussion}

\subsection{Assessment of the diagenetic state of rhynchonellid shells}

Generally, the activation of luminescence is likely due to the presence of $\mathrm{Mn}$, whereas $\mathrm{Fe}$ acts as a quencher (Heydari and Moore 1993; Barbin and Gaspard 1995). On the other hand, Mn concentration may increase as a result of enhanced diagenetic effects (Meyers 1991), thus triggering the luminescence. This implies that the secondary layers of the here-studied rhynchonellids, which are non luminescent, were precipitated in equilibrium with seawater, and that they did not undergo any post-depositional recrystallisation (Popp et al. 1986; Brand et al. 2003; Shields et al. 2003).

The quality of preservation has also been checked by using $(\mathrm{Sr} / \mathrm{Ca}) \times 1,000$ to $\mathrm{Mn}$ and $\mathrm{Sr} / \mathrm{Mg}$ to $\mathrm{Mn} / \mathrm{Mg}$ crossplots, for which the fields of stability for well-preserved brachiopods are defined. The analysed brachiopods from the western Swiss Jura fall within the stability fields, except for four samples that may have undergone a more pronounced diagenetic overprint compared to the rest of the selected fossils (Fig. 5). Moreover, Mn contents are coherent with the range of values postulated for well-preserved, modern brachiopods by Brand et al. (2003), as only two samples have a Mn content above or just below the

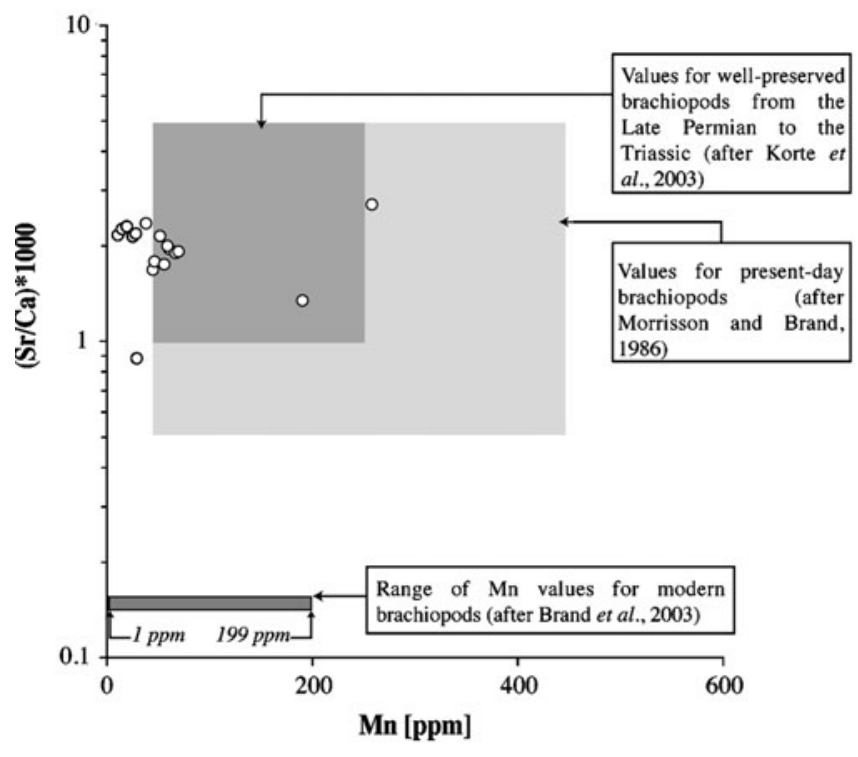

maximum value of $200 \mathrm{ppm}$ proposed by these authors. As a consequence, ${ }^{87} \mathrm{Sr} /{ }^{86} \mathrm{Sr}$ measured on samples $\mathrm{C}+160 \mathrm{~b}$ and MC1c ([Mn] of 257.59 and $190.35 \mathrm{ppm}$, respectively, Table 1) have been discarded from the dataset.

Consequently, diagenesis may have altered the Sr-isotope values of five rhynchonellids (samples in italics in Table 1). Generally, $\mathrm{Mg}$ contents are relatively high, mostly above 900 ppm (Table 1; compare with well preserved, Cenomanian brachiopods in Voigt et al. 2003, whose measured values are below $900 \mathrm{ppm}$ ). Diagenesis alone cannot account for such results, as Mg concentrations naturally vary in seawater (e.g., Bruckschen et al. 1999).

\subsection{Interpretation of the rhynchonellid ${ }^{87} \mathrm{Sr} /{ }^{86} \mathrm{Sr}$ data as a dating tool}

Gradients in the temporal evolution of the ${ }^{87} \mathrm{Sr} /{ }^{86} \mathrm{Sr}$ ratio are used to attribute a numerical age to sedimentary rocks (e.g., McArthur et al. 2001), especially since this ratio is constant throughout all oceans for a certain time, as the residence time of $\mathrm{Sr}$ in oceans is far longer than their mixing periodicity (Allègre et al. 2010). For the time span from the Early Hauterivian to the earliest Aptian, a recently established belemnite ${ }^{87} \mathrm{Sr} /{ }^{86} \mathrm{Sr}$ curve (Fig. 6; McArthur et al. 2004, 2007; Bodin et al. 2009) is distinctive enough to differentiate Hauterivian from Barremian and Aptian samples. The Sr-isotope ratio slowly shifts toward more radiogenic values from the Early Hauterivian to the late Early Barremian (Kotetishvilia compressissima zone), and values decrease upward from the early Late Barremian (Holcodiscus uhligi zone) until the earliest Aptian (Fig. 6;

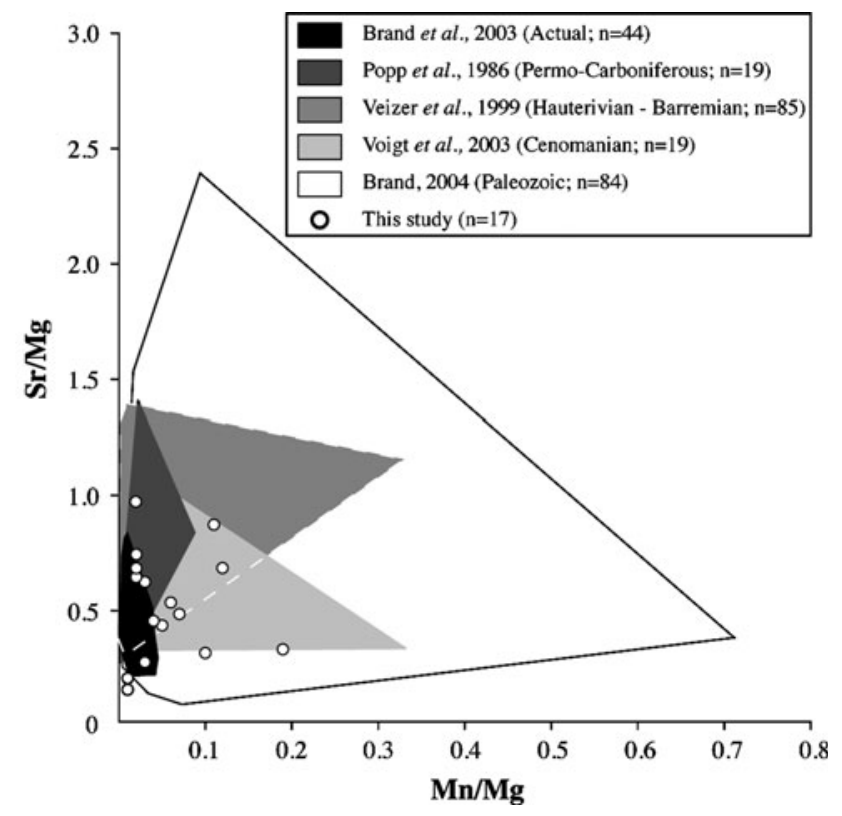

Fig. $5(\mathrm{Sr} / \mathrm{Ca}) \times 1,000$ to $\mathrm{Mn}$, and $\mathrm{Sr} / \mathrm{Mg}$ to $\mathrm{Mn} / \mathrm{Mg}$ cross plots of the analysed rhynchonellids from the western Swiss Jura 


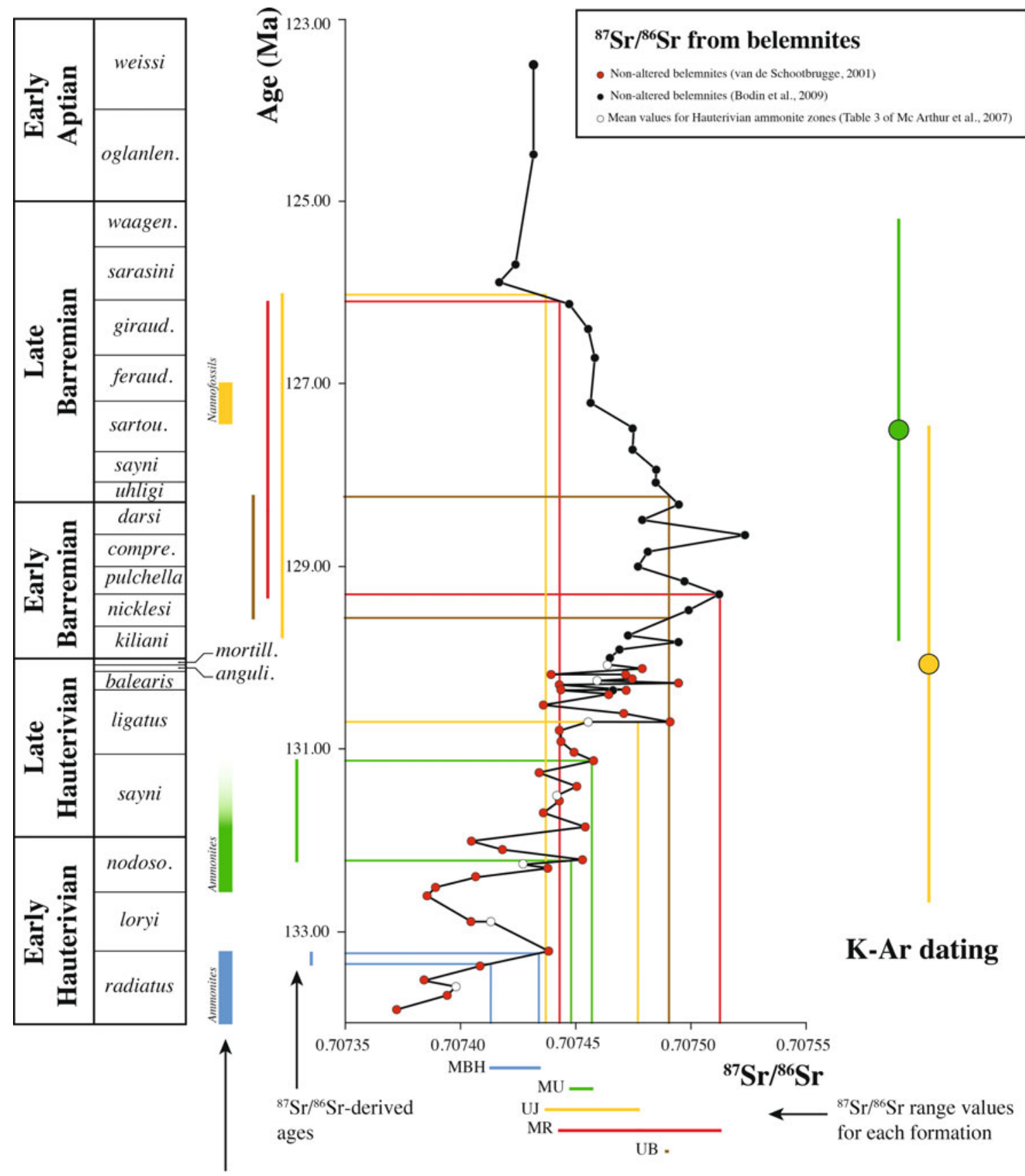

Biostratigraphical constraints (after Busnardo \& Thieuloy, 1989, and Godet et al., 2010)

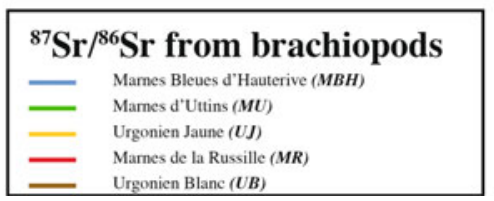

Fig. 6 Comparison of the Sr-isotope ratios measured on rhynchonellids from the western Swiss Jura with the ammonite-calibrated ${ }^{87} \mathrm{Sr} /{ }^{86} \mathrm{Sr}$ curve obtained from belemnites from the Vocontian Trough

cf. Jones and Jenkyns 2001; McArthur et al. 2004, 2007; Bodin et al. 2009).

A comparison of the belemnite and rhynchonellid $\mathrm{Sr}$-isotope curves reveals that the values obtained for (data from van de Schootbrugge 2001; McArthur et al. 2007; Bodin et al. 2009). Absolute ages on the vertical axis are after the ICS Timescale (2009)

brachiopods from the "Marnes bleues d'Hauterive", which are calibrated in time by ammonite biostratigraphy (Acanthodiscus radiatus and Crioceratites loryi zones; Busnardo and Thieuloy 1989), are comparable to the 
highest ${ }^{87} \mathrm{Sr} /{ }^{86} \mathrm{Sr}$ values measured in belemnites from the A. radiatus and $C$. loryi zones (Fig. 6). In particular, these results suggest than the deposition of the "Marnes bleues d'Hauterive" occurred close to the boundary between the A. radiatus and $C$. loryi zones. The mean ${ }^{87} \mathrm{Sr} /{ }^{86} \mathrm{Sr}$-derived age value (132.29 Ma, Table 3) corresponds particularly well to the age range to be expected from the biostratigraphical indications calibrated against the most recent time table compiled by the International Commission on Stratigraphy (ICS 2009).

${ }^{87} \mathrm{Sr} /{ }^{86} \mathrm{Sr}$ measurements performed on rhynchonellids from the "Marnes d'Uttins" exhibit a rather high variability, with a range of 0.000059 (Table 3); this may suggest that a longer time period is contained within this formation, especially since the short-term variability of the belemnite record is comparable to the one displayed by brachiopod values. The Sr-isotope ratios from the "Marnes d'Uttins" overlap with those from belemnites from the Lyticoceras nodosoplicatum zone up to the uppermost part of the Subsaynella sayni zone. In more detail, the two lowest rhynchonellid ${ }^{87} \mathrm{Sr} /{ }^{86} \mathrm{Sr}$ values are correlatable with corresponding belemnite values for the L. nodosoplicatum to the $S$. sayni zone, whereas the highest acceptable value (0.70751 for sample MC1a) appears enriched in radiogenic $\mathrm{Sr}$, as the highest belemnite value in this time interval is 0.70746 (van de Schootbrugge 2001). As the age of the "Marnes d'Uttins" is relatively well constrained by ammonite biostratigraphy to the L. nodosoplicatum, and possibly up to the $S$. sayni zone (see discussion in Godet et al. 2010), the ${ }^{87} \mathrm{Sr} /{ }^{86} \mathrm{Sr}$ ratio from sample MCla may not reflect an original seawater signal, but may result from interaction with a more radiogenic $\mathrm{Sr}$ source during or sometimes after its deposition. On the other hand, strontium model ages for samples MC3a and MC4 are coherent with available biostratigraphic data, confirming the validity of our results. The average ${ }^{87} \mathrm{Sr} /{ }^{86} \mathrm{Sr}$-derived age (131.68 Ma) is in good accordance with the younger end of biostratigraphical age range (Table 3 ).

The three rhynchonellids from the "Urgonien Jaune" display isotope ratios ranging between 0.70744 and 0.70748 (see Fig. 6; Table 3). Based on these values and given the shape of the $\mathrm{Sr}$-isotopes reference curve, the "Urgonien Jaune" may be attributed to a period of time ranging from the Early to the Late Barremian (Avramidiscus kiliani to Martellites sarasini zones, respectively). Such a long period of time (3.7 Ma on Fig. 6) is not incompatible with previous conclusions on the age of this formation. Detailed sedimentological investigation near the base of the "Urgonien Jaune" in the Eclépens section reveals the presence of repetitive levels of allochthonous sediments, intercalated with a glauconite-rich and phosphate-bearing level. Repeated discontinuities associated with breccia are interpreted as stacked sequence boundaries




(Godet et al. 2010). This basal interval of the "Urgonien Jaune" is dated as Late Hauterivian to earliest Late Barremian (latest Balearites balearis to $H$. uhligi zones; Arnaud 2005; Godet et al. 2010). The marly horizons where the rhynchonellids were collected are in the upper part of this basal series, and the calcareous nannofossils described from the same layers are indicative of the Gerardthia sartousiana-Hemihoplites feraudianus zones (Godet et al. 2010), which is coherent with the highest ${ }^{87} \mathrm{Sr} /{ }^{86} \mathrm{Sr}$ values recorded from this interval. Moreover, the presence of this age-diagnostic nannofossils assemblage excludes the correlation of the measured ${ }^{87} \mathrm{Sr} /{ }^{86} \mathrm{Sr}$ with the increasing part of the reference curve. In other words, the average ${ }^{87} \mathrm{Sr} /{ }^{86} \mathrm{Sr}$ age (127.94 Ma, Table 3) is quite well in accordance with the nannofossil-derived age for these levels.

Following on top, the four rhynchonellids of the "Marnes de la Russille" and the base of the "Urgonien Blanc" display rather disparate values (0.70744-0.70751 and 0.707490 for the "Marnes de la Russille" and the "Urgonien Blanc", respectively; see Fig. 6). Although the average ${ }^{87} \mathrm{Sr} /{ }^{86} \mathrm{Sr}$ age for the "Marnes de la Russille" (127.75 Ma, Table 3) is in perfect accordance with the accepted biostratigraphical and sequence stratigraphical age, this is not the case for the uppermost studied formation. Indeed for the "Urgonien Blanc", only one reliable measure (0.707490, Table 1; Fig. 6) is present, as the rhynchonellid from sediments near the top of the "Urgonien Blanc" (sample VA61, Vaumarcus section; Fig. 6; Table 1) is diagenetically altered and its ${ }^{87} \mathrm{Sr} /{ }^{86} \mathrm{Sr}$ value cannot be used. Moreover, the ${ }^{87} \mathrm{Sr} /{ }^{86} \mathrm{Sr}$ model age for the "Urgonien Blanc" (128.36 Ma, Table 3) is offset by at least 1 Ma compared to absolute dating that could be derived from biostratigraphical and sequence stratigraphical information provided for the upper part of this formation (127.4-126.7 Ma, Table 3). More values are needed here to obtain an adequate age indication.

To summarize, the general spread in the rhynchonellid ${ }^{87} \mathrm{Sr} /{ }^{86} \mathrm{Sr}$ data may reflect a natural variability, as is also seen in the hemipelagic belemnites with a similar and even higher range of values, and as such, the average ${ }^{87} \mathrm{Sr} /{ }^{86} \mathrm{Sr}$ ages obtained here are more viable than individual ages based on single specimen (cf. Table 3 ). The comparison of the ${ }^{87} \mathrm{Sr} /{ }^{86} \mathrm{Sr}$-derived ages with available biostratigraphic data reveals a clear agreement between both approaches for the "Marnes bleues d'Hauterive", the "Marnes d'Uttins" and the "Urgonien Jaune", which are attributed to the $A$. radiatus, L. nodosoplicatum to $S$. sayni and $G$. sartousiana to $H$. feraudianus ammonite zones, respectively (see Table 3 for the corresponding absolute ages derived from the calibration of ammonite zones published in Ogg et al. 2008). For the "Marnes de la Russille" and the "Urgonien Blanc", the correlation is less robust, and this is certainly due either to the low number of analysed specimens, or to diagenetic alteration. It is especially the case for the "Urgonien Blanc", whose ${ }^{87} \mathrm{Sr} /{ }^{86} \mathrm{Sr}$ - derived age is at least $1 \mathrm{Ma}$ too old compared to absolute age derived from biostratigraphy and sequence stratigraphy. Finally, it is important to highlight that even if absolute dating can be derived from these ${ }^{87} \mathrm{Sr} /{ }^{86} \mathrm{Sr}$ measurements, as shown in Table 3, the use of an ammonite-calibrated reference curve ensures the future validity and biostratigraphic meaning of these ages even if the dating of the stage boundaries would be challenged.

\subsection{Reliability of the K-Ar chronometer applied} to glauconite from the western Swiss Jura

The morphology and the colour of glauconite grains provide a possibility to rapidly assess the maturity of the material. In samples of the "Marnes d'Uttins" and the lowermost part of the "Urgonien Jaune", both the "pop-corn" shape, as well as the dark-green colour of the majority of the separated particles, indicate that the glauconites analysed here are relatively evolved and the glauconitisation process reached stage 3 in Figure 12 of Odin and Matter (1981). Moreover, XRD analysis reveals the presence of relatively wellevolved glauconite, even if the presence of high calcite peaks (at 29.45 and $43.15^{\circ} 2 \theta$ ) tends to decrease the intensity of glauconite peaks. Finally, the high $\mathrm{K}_{2} \mathrm{O}$ content (above 6\% in all cases) corresponds to evolved glauconites (Odin and Matter 1981). Consequently, all requirements for glauconitic minerals from both stratigraphical levels to give reliable K-Ar results are satisfied (Clauer et al. 1992; Stille and Clauer 1994).

The obtained ages are identical within analytical errors, and cannot help in estimating the time span between the "Marnes d'Uttins" and the "Urgonien Jaune". In spite of this, the values are rather meaningful, if compared to the timescale of the ICS 2009; combined together, both results $(130.7 \pm 2.6$ and $127.5 \pm 2.3 \mathrm{Ma}$ ) would correspond to the Late Hauterivian to the early Late Barremian. Moreover, whereas the glauconite age of the "Marnes d'Uttins" appears too young relative to its ammonite age (latest Early to eventually earliest Late Hauterivian; Fig. 3), the glauconite age of the basal interval of the "Urgonien Jaune" fits the age attributed by sequence-stratigraphical correlation (latest Hauterivian to Early Barremian; Godet et al. 2010). Moreover, this dating is coherent with the strontium model ages previously discussed for the "Urgonien Jaune".

In the case of the "Marnes d'Uttins", two mechanisms may account for low K-Ar ages: Ar loss or K gain (Téllez Duarte and López Martínez 2002), even if the first process is the most common (e.g., Schaltegger et al. 1995). The glauconites of the "Marnes d'Uttins" were generated in association with a well-developed, glauconite-rich 
hardground, which documents different stages of cementation by glauconite, phosphate and chert; the latter lithology is also prominent immediately underneath the hardground, in the higher part of the lower "Pierre Jaune de Neuchâtel" (Godet et al. 2010). Complex interactions between mineralisation processes and fluid flow may have taken place during the early stages of diagenesis in the hardground associated with the "Marnes d'Uttins" (e.g., Godet 2006). This may have induced the early diagenetic loss of Ar. An alternative would be the alteration of glauconite from the "Marnes d'Uttins" by diagenetic fluids; the variability of ${ }^{87} \mathrm{Sr} /{ }^{86} \mathrm{Sr}$ values obtained for brachiopods from the "Marnes d'Uttins", and especially the too radiogenic ratio of sample MC1a, may support this hypothesis.

\subsection{Implications of the geochemical age-models} for the timing of the evolution of the Urgonian platform in the western Swiss Jura

The ages discussed here are conform with recently published dating obtained both by ammonite and nannofossil biostratigraphy, sequence stratigraphy, the correlation of platform drowning pattern in the western Swiss Jura with that of the well-dated Helvetic platform succession, and trends in kaolinite and phosphorus contents (Godet et al. 2008, 2010). Especially the age for the onset of the Urgonian platform (middle Late Barremian) seems compatible with similar ages in the Helvetic realm (Bodin et al. 2006b; Föllmi et al. 2007) and southeastern France (Arnaud et al. 1998; Arnaud 2005). As such, the evolution of this proximal part of the Lower Cretaceous carbonate platform is as a whole clearly comparable to those in the aforementioned adjacent areas. The glauconite and phosphatic layers at the base of the "Marnes d'Uttins" and near the base of the "Urgonien Jaune" analysed for their $\mathrm{K}-\mathrm{Ar}$ ages have been interpreted as platform-drowning unconformities (Godet et al. 2010). They are correlated with similar layers in the Helvetic realm (Lidernen and Altmann Members; late Early to early Late Hauterivian, and latest Hauterivian to late Early Barremian). Phases of heterozoan carbonate production preserved in the lower "Pierre Jaune de Neuchâtel", upper "Pierre Jaune de Neuchâtel" and "Urgonien Jaune" are comparable with coeval phases in the Helvetic realm (Hauterivian Kieselkalk Fm and lower Upper Barremian Tierwis Fm; Föllmi et al. 2007); the onset of oligotrophic conditions is also reported from the Late Barremian of the eastern Arabian plate (Schroeder et al. 2010).

These correlations suggest that the evolution of the inner part of the carbonate platform, as documented in the western Swiss Jura Mountains, was not only subjected to sea-level change, but also to palaeoceanographical change, such as changes in the nutrient regime and surface water temperature, documented by change from photozoan to heterozoan carbonate production that ultimately triggered phases of platform drowning.

\section{Conclusions}

${ }^{87} \mathrm{Sr} /{ }^{86} \mathrm{Sr}$ ratios of well-preserved rhynchonellid shells from Lower Cretaceous platform sediments in the western Swiss Jura have been compared to a reference curve established on belemnite rostra from hemipelagic settings, and provide model ages that are coherent with available biostratigraphical data and sequence stratigraphical interpretations. They confirm a middle Late Barremian age for the onset of Urgonian platform build up. Glauconites of a basal level in the underlying "Urgonien Jaune" deliver equally a stratigraphic meaningful $\mathrm{K}-\mathrm{Ar}$ age $(130.7 \pm 2.6 \mathrm{Ma}$ : latest Hauterivian to Early Barremian). Glauconites associated with the hardground of the "Marnes d'Uttins" have, however, suffered from diagenetic resetting, as indicated by the too young $\mathrm{K}-\mathrm{Ar}$ age $(127.5 \pm 2.3 \mathrm{Ma})$.

The obtained age models for the Lower Cretaceous sediments of the western Swiss Jura allow their proper integration into a larger sequence-stratigraphical and palaeoceanographic framework, where phases of photozoan and heterozoan carbonate production and of platform drowning are correlated with those in neighboured areas.

Acknowledgments The authors are grateful to Mireille Leboeuf and Massoud Dadras (University of Neuchâtel), and to André Strasser (University of Fribourg), for their help with SEM and cathodoluminescence microscopy, respectively. We thank Tiffany Monnier and André Villard (University of Neuchâtel), who performed the preparation of brachiopod samples for the ICP-MS analyses and thin sections of the shells. We also thank Th. Perrone and J.-J. Frey of the Centre de Géochimie de la Surface at the University of Strasbourg, France, for their technical assistance and analytical work. The staff of the Holcim quarry at Eclépens and especially François Girod and Claude Brocard are gratefully acknowledged for their permission to sample the Eclépens section and for their continuous interest. We are grateful to Annie and Hubert Arnaud (University of Grenoble, France) for their assistance throughout this work, and Danièle Gaspard (University of Paris Sud, France) for the identification of the brachiopods. Adrian Immenhauser (University of Bochum, Germany) and Bernard Pittet (University of Lyon 1, France) reviewed this paper; they are gratefully acknowledged for their constructive comments and suggestions, as well as handling editor Alan G. Milnes. The financial support of the Swiss National Science Foundation (projects no. $2100-067807 / 1$ and 200020-105206/1) is warmly acknowledged. This is EOST contribution 2010-202-UMR7517.

\section{References}

Allègre, C. J., Louvat, P., Gaillardet, J., Meynadier, L., Rad, S., \& Capmas, F. (2010). The fundamental role of island arc weathering in the oceanic $\mathrm{Sr}$ isotope budget. Earth and Planetary Science Letters, 292, 51-56. 
Arnaud, H. (2005). The South-East France Basin (SFB) and its mesozoic evolution. In T. Adatte, A. Arnaud-Vanneau, H. Arnaud, M.-C. Blanc-Aletru, S. Bodin, E. Carrio-Schaffhauser, K. B. Föllmi, A. Godet, M. C. Raddadi, \& J. Vermeulen (Eds.), The Hauterivian-Lower Aptian sequence stratigraphy from Jura Platform to Vocontian Basin: A multidisciplinary approach (pp. 5-28). Géologie Alpine, Série Spéciale "Colloques et Excursions" No. 7.

Arnaud, H., Arnaud-Vanneau, A., Blanc-Aletru, M. C., Adatte, T., Argot, M., Delanoy, G., et al. (1998). Répartition stratigraphique des orbitolinidés de la plate-forme urgonienne subalpine et jurassienne (SE de la France). Géologie Alpine, 74, 3-89.

Arnaud-Vanneau, A., \& Arnaud, H. (1990). Hauterivian to Lower Aptian carbonate shelf sedimentation and sequence stratigraphy in the Jura and northern Subalpine chains (southeastern France and Swiss Jura). In M. E. Tucker, J. L. Wilson, P. D. Crevello, J. R. Sarg, \& J. F. Read (Eds.), Carbonate platforms: Facies, sequences and evolution (pp. 203-233). Oxford: Blackwell Scientific Publications, Special Publication of the International Association of Sedimentologists No. 9.

Barbin, V., \& Gaspard, D. (1995). Cathodoluminescence of recent articulate brachiopod shells. Implications for growth stages and diagenesis evaluation. Geobios, 18, 39-45.

Ben Youssef, M., \& Peybernès, B. (1986). Données micropaléontologiques et biostratigraphiques nouvelles sur le Crétacé inférieur marin du Sud-Tunisien. Journal of African Earth Sciences, 5, 217-231.

Bernaus, J. M., Arnaud-Vanneau, A., \& Caus, E. (2003). Carbonate platform sequence stratigraphy in a rapidly subsiding area: The Late Barremian-Early Aptian of the Organya basin, Spanish Pyrenees. Sedimentary Geology, 159, 177-201.

Blanc-Aletru, M. C. (1995). Importance des discontinuités dans l'enregistrement sédimentaire de l'Urgonien jurassien. Micropaléontologie, Sédimentologie, Minéralogie et Stratigraphie Séquentielle. PhD Thesis. Grenoble, France: Laboratoire de Géologie de l'Université I de Grenoble, $321 \mathrm{p}$.

Bodin, S., Fiet, N., Godet, A., Matera, V., Westermann, S., Clément, A., et al. (2009). Early Cretaceous (late Berriasian to early Aptian) palaeoceanographic change along the northwestern Tethyan margin (Vocontian Trough, southeastern France): $\delta^{13} \mathrm{C}, \delta^{18} \mathrm{O}$ and $\mathrm{Sr}$-isotope belemnite and whole-rock records. Cretaceous Research, 30, 1247-1262.

Bodin, S., Godet, A., Vermeulen, J., Arnaud, H., Strasser, A., Fiet, N., et al. (2006a). The late Hauterivian Faraoni oceanic anoxic event in the western Tethys: Evidence from phosphorus burial rates. Palaeogeography, Palaeoclimatology, Palaeoecology, 235, 245-264.

Bodin, S., Godet, A., Vermeulen, J., Linder, P., \& Föllmi, K. B. (2006b). Biostratigraphy, sedimentology and sequence stratigraphy of the latest Hauterivian-early Barremian drowning episode of the Northern Tethyan margin (Altmann Member, Helvetic Nappes, Switzerland). Eclogae geologicae Helvetiae, 99, 157-174.

Bonhomme, M. G., Thuizat, R., Pinault, Y., Clauer, N., Wendling, R., \& Winkler, R. (1975). Méthode de potassium-argon. Appareillage et technique. Note tech. Inst. de Géologie, Univ. L. Pasteur, Strasbourg, 3, 1-53.

Boyle, E. A., \& Keigwin, L. D. (1985/86). Comparison of Atlantic and Pacific paleochemical records for the last 215,000 years: Changes in deep ocean circulation and chemical inventories. Earth and Planetary Science Letters, 76, 135-150.

Brand, U. (2004). Carbon, oxygen and strontium isotopes in Paleozoic carbonate components: An evaluation of original seawaterchemistry proxies. Chemical Geology, 204, 23-44.

Brand, U., Logan, A., Hiller, N., \& Richardson, J. (2003). Geochemistry of modern brachiopods: Applications and implications for oceanography and paleoceanography. Chemical Geology, 198, 305-334.

Bruckschen, P., Oesmann, S., \& Veizer, J. (1999). Isotope stratigraphy of the European Carboniferous: Proxy signals for ocean chemistry, climate and tectonics. Chemical Geology, 161, 127-163.

Busnardo, R., \& Thieuloy, J.-P. (1989). Les ammonites de l'Hauterivien jurassien: Révision des faunes de la région du stratotype historique de l'étage Hauterivien. Mémoires de la Société neuchâteloise des Sciences naturelles, XI, 101-147.

Carpenter, S. J., \& Lohmann, K. C. (1995). $\delta^{18} \mathrm{O}$ and $\delta^{13} \mathrm{C}$ values of modern brachiopod shells. Geochimica et Cosmochimica Acta, 59, 3749-3764.

Clauer, N., Stille, P., Keppens, E., \& O’Neil, J. (1992). Le mécanisme de la glauconitisation: Apports de la géochimie isotopique du strontium, du néodyme et de l'oxygène de glauconies récentes. Comptes Rendus de l'Academie des Sciences, Serie 2, Mecanique, Physique, Chimie, Sciences de l'Univers, Sciences de la Terre, 315, 321-327.

Clavel, B., Charollais, J., Conrad, M. A., Jan du Chêne, R., Busnardo, R., Gardin, S., et al. (2007). Dating the progradation of the Urgonian limestone from the Swiss Jura to South East France. Zeitschrift der Deutschen Gesellschaft für Geowissenschaften, 158, 1025-1062.

Föllmi, K. B., Bodin, S., Godet, A., Linder, P., \& van de Schootbrugge, B. (2007). Unlocking paleo-environmental interaction from Early Cretaceous shelf sediments in the Helvetic Alps: Stratigraphy is the key! Swiss Journal of Geosciences, 100, 349-369.

Föllmi, K. B., Godet, A., Bodin, S., \& Linder, P. (2006). Interactions between environmental change and shallow-water carbonate build-up along the northern Tethyan margin and their impact on the early Cretaceous carbon-isotope record. Paleoceanography, 21. doi:10.1029/2006PA001313.

Funk, H., Föllmi, K. B., \& Mohr, H. (1993). Evolution of the Tithonian-Aptian carbonate platform along the northern Tethyan margin, eastern Helvetic Alps. In J. A. T. Simo, R. W. Scott, \& J. P. Masse (Eds.), Cretaceous carbonates platforms (pp. 387-407). Tulsa: AAPG (American Association of Petroleum Geologists), Memoir 56.

Godet, A. (2006). The evolution of the Urgonian platform in the Western Swiss Jura realm and its interactions with palaeoclimatic and palaeoceanographic change along the Northern Tethyan Margin (Hauterivian-earliest Aptian). PhD Thesis. Neuchâtel, Switzerland: Université de Neuchâtel, 405 p.

Godet, A., Bodin, S., Adatte, T., \& Föllmi, K. B. (2008). Platforminduced clay-mineral fractionation along a northern Tethyan basin-platform transect: Implications for the interpretation of Early Cretaceous climate change (Late Hauterivian-Early Aptian). Cretaceous Research, 29, 830-847.

Godet, A., Föllmi, K. B., Bodin, S., de Kaenel, E., Matera, V., \& Adatte, T. (2010). Stratigraphic, sedimentological and palaeoenvironmental constraints on the rise of the Urgonian platform in the western Swiss Jura. Sedimentology, 57, 1088-1125.

Heydari, E., \& Moore, C. H. (1993). Zonation and geochemical patterns of burial calcite cements: Upper Smackover Formation, Clarke County, Mississippi. Journal of Sedimentary Petrology, 63, 44-60.

ICS. (2009). International Stratigraphic Chart 2009. http://www. stratigraphy.org/column.php?id=Chart/Time\%20Scale. Accessed 9 Feb 2010.

Immenhauser, A., Hillgärtner, H., Sattler, U., Bertotti, G., Schoepfer, P., Homewood, P., et al. (2004). Barremian-lower Aptian Qishn Formation, Haushi-Huqf area, Oman: A new outcrop analogue for the Kharaib/Shu'aiba reservoirs. GeoArabia, 9, 153-194. 
Jones, C. E., \& Jenkyns, H. C. (2001). Seawater strontium isotopes, oceanic anoxic events, and seafloor hydrothermal activity in the Jurassic and Cretaceous. American Journal of Science, 301, 112-149.

Korte, C., Kozur, H. W., Bruckschen, P., \& Veizer, J. (2003). Strontium isotope evolution of Late Permian and Triassic seawater. Geochimica et Cosmochimica Acta, 67, 47-62.

Masse, J.-P. (1993). Valanginian-Early Aptian carbonate platforms from Provence, Southeastern France. In J. A. T. Simo, R. W. Scott, \& J.-P. Masse (Eds.), Cretaceous carbonate platforms (pp. 363-375). Tulsa: AAPG (American Association of Petroleum Geologists), Memoir 56.

McArthur, J. M., Janssen, N. M. M., Reboulet, S., Leng, M. J., Thirwall, M. F., \& van de Schootbrugge, B. (2007). Palaeotemperature, polar ice-volume, and isotope stratigraphy $(\mathrm{Mg} / \mathrm{Ca}$, $\delta^{18} \mathrm{O}, \quad \delta^{13} \mathrm{C},{ }^{87} \mathrm{Sr} /{ }^{86} \mathrm{Sr}$ ): The Early Cretaceous (Berriasian, Valanginian, Hauterivian). Palaeogeography, Palaeoclimatology, Palaeoecology, 248, 391-430.

McArthur, J. M., Howarth, R. J., \& Bailey, T. R. (2001). Strontium isotope stratigraphy: LOWESS version 3: Best fit to the marine Sr-isotope curve for 0-509 Ma and accompanying look-up table for deriving numerical age. The Journal of Geology, 109, 155-170.

McArthur, J. M., Mutterlose, J., Price, G. D., Rawson, P. F., Ruffell, A., \& Thirlwall, M. F. (2004). Belemnites of Valanginian, Hauterivian and Barremian age: $\mathrm{Sr}$-isotope stratigraphy, composition $\left({ }^{87} \mathrm{Sr} /{ }^{86} \mathrm{Sr}, \quad \delta^{13} \mathrm{C}, \quad \delta^{18} \mathrm{O}, \mathrm{Na}, \mathrm{Sr}, \mathrm{Mg}\right)$, and palaeooceanography. Palaeogeography, Palaeoclimatology, Palaeoecology, 202, 253-272.

Meyers, W. J. (1991). Calcite cement stratigraphy: An overview. In C. E. Barker \& O. C. Kopp (Eds.), Luminescence microscopy and spectroscopy: Qualitative and quantitative application (pp. 133-148). SEPM Short Course Notes No. 25.

Michalik, J. (1994). Lower Cretaceous carbonate platform facies, western Carpathians. Palaeogeography, Palaeoclimatology, Palaeoecology, 111, 263-277.

Moore, D. M., \& Reynolds, R. C. J. (1997). X-ray diffraction and the identification and analysis of clay minerals. New York: Oxford University Press.

Morrison, J. O., \& Brand, U. (1986). Paleoscene \#5. Geochemistry of Recent Marine Invertebrates. Geoscience Canada, 13, 237-254.

Odin, G. S., \& Fullagar, P. D. (1988). Geological significance of the Glaucony Facies. In G. S. Odin (Ed.), Green marine clays (pp. 95-332). Amsterdam: Elsevier.

Odin, G. S., \& Matter, A. (1981). De glauconiarum origine. Sedimentology, 28, 611-641.

Ogg, J. G., Ogg, G., \& Gradstein, F. M. (2008). The concise geologic time scale. New York: Cambridge University Press.

Pittet, B., van Buchem, F. S. P., Hillgärtner, H., Razin, P., Grötsch, J., \& Droste, H. (2002). Ecological succession, palaeoenvironmental change, and depositional sequences of Barremian-Aptian shallow-water carbonates in northern Oman. Sedimentology, 49, 555-581.

Popp, B. N., Anderson, T. F., \& Sandberg, P. A. (1986). Brachiopods as indicators of original isotopic compositions in some Paleozoic limestones. GSA Bulletin, 97, 1262-1269.

Remane, J., Busnardo, R., \& Charollais, J. (1989). Révision de l'étage Hauterivien (région-type et environs, Jura franco-suisse). Neuchâtel: Société Neuchâteloise des Sciences Naturelles, Memoir XI.

Renevier, E. (1874). Tableau des terrains sédimentaires formés pendant les époques de la phase organique du globe terrestre avec leurs représentants en Suisse et dans les régions classiques, leurs synonymes et les principaux fossiles de chaque étage. Bulletin de la Société vaudoise des Sciences naturelles, 13, 218-252.

Schaltegger, U., Zwingmann, H., Clauer, N., Larqué, P., \& Stille, P. (1995). K-Ar dating of a Mesozoic hydrothermal activity in Carboniferous to Triassic clay minerals of northern Switzerland. Schweizerische Mineralogische und Petrographische Mitteilungen, 75, 163-176.

Schroeder, R., van Buchem, F. S. P., Cherchi, A., Baghbani, D., Vincent, B., Immenhauser, A., \& Granier, B. (2010). Revised orbitolinid biostratigraphic zonation for the Barremian-Aptian of the eastern Arabian Plate and implications for regional stratigraphic correlations. In F. S. P. van Buchem, M. I. Al-Husseini, F. Maurer, \& H. J. Droste (Eds.), Barremian-Aptian stratigraphy and hydrocarbon habitat of the Eastern Arabian Plate (Vol. I, pp. 49-96). Manama: Gulf PetroLink. GeoArabia Special Publication 4.

Shields, G. A., Carden, G. A. F., Veizer, J., Meidla, T., Rong, J.-Y., \& Li, R.-Y. (2003). Sr, C, and O isotope geochemistry of Ordovician brachiopods: A major isotopic event around the Middle-Late Ordovician transition. Geochimica et Cosmochimica Acta, 67, 2005-2025.

Stille, P., \& Clauer, N. (1994). The process of glauconitization: Chemical and isotopic evidence. Contributions to Mineralogy and Petrology, 117, 253-262.

Stille, P., Riggs, S., Clauer, N., Ames, D., Crowson, R., \& Snyder, S. (1994). Sr and $\mathrm{Nd}$ isotopic analysis of phosphorite sedimentation through one Miocene high-frequency depositional cycle on the North Carolina continental shelf. Marine Geology, 117, 253-273.

Téllez Duarte, M. A., \& López Martínez, M. (2002). K-Ar dating and geological significance of clastic sediments of the Paleocene Sepultura Formation, Baja California, Mexico. Journal of South American Earth Sciences, 15, 725-730.

van Buchem, F. S. P., Al-Husseini, M. I., Maurer, F., Droste, H. J., \& Yose, L. A. (2010). Sequence-stratigraphic synthesis of the Barremian-Aptian of the eastern Arabian Plate and implications for the petroleum habitat. In F. S. P. van Buchem, M. I. Al-Husseini, F. Maurer, \& H. J. Droste (Eds.), BarremianAptian stratigraphy and hydrocarbon habitat of the Eastern Arabian Plate (Vol. I, pp. 9-48). Manama: Gulf PetroLink. GeoArabia Special Publication 4.

van Buchem, F. S. P., Pittet, B., Hillgärtner, H., Grötsch, J., Al-Mansouri, A. I., Billing, L., et al. (2002). High-resolution sequence stratigraphic architecture of Barremian/Aptian carbonate systems in northern Oman and the United Arab Emirates (Kharaib and Shu'aiba formations). GeoArabia, 7, 461-500.

van de Schootbrugge, B. (2001). Influence of paleo-environmental changes during the Hauterivian (early Cretaceous) on carbonate deposition along the northern margin of the Tethys: Evidence from geochemical records ( $\mathrm{C}, \mathrm{O}$ and $\mathrm{Sr}$-isotopes, $\mathrm{P}, \mathrm{Fe}, \mathrm{Mn}$ ). PhD Thesis. Neuchâtel, Switzerland: Université de Neuchâtel, $291 \mathrm{p}$.

Veizer, J., Ala, D., Azmy, K., Bruckschen, P., Buhl, D., Bruhn, F., et al. (1999). ${ }^{87} \mathrm{Sr} /{ }^{86} \mathrm{Sr}, \delta^{13} \mathrm{C}$ and $\delta^{18} \mathrm{O}$ evolution of Phanerozoic seawater. Chemical Geology, 161, 59-88.

Voigt, S., Wilmsen, M., Mortimore, R. N., \& Voigt, T. (2003). Cenomanian palaeotemperatures derived from the oxygen isotopic composition of brachiopods and belemnites: Evaluation of Cretaceous palaeotemperatures proxies. International Journal of Earth Science (Geol. Rundsch.), 92, 285-299. 